\title{
RESEARCH NOTE/NOTE DE RECHERCHE
}

\section{Problems of Objectivity in Oral History ${ }^{1}$}

\author{
Henry W. Hodysh and R. Gordon McIntosh
}

The past has happened and cannot change, but the interpretation and understanding of it continues to happen and will never stop changing. D. Henige, Oral Historiography (London: Longman, 1982), 129.

Educational historians in studying the period following 1945 have quite rightly relied on official records, diaries, and letters to account, as Ranke would say, for "what actially happened" (1956, p. 57). The proximity of this period to the present, however, provides the historian with an opportunity to search beyond the documentary evidence and to enlist the findings of oral history in order to understand the activities and motivations of individuals who functioned as catalysts in the implementation of educational change. Such an approach may lead to new interpretations of the past and, in the process, suggest avenues of inquiry that have yet to be explored (Thompson, 1978, p. 63). One such avenue takes into account the idea of objectivity, best defined, perhaps, as the achievement of a "superior" explanation of events, one that better than any other accurately reflects the historical state of affairs (Gorman, 1981, p. 131). From the standpoint of the oral historian, what, then, are the possibilities of objectivity in the description and explanation of events?

\section{The Context of Objectivity}

The study of objectivity in the field of oral history presupposes an understanding of the meaning and purpose of oral history itself. In this setting oral history may be defined as the description and explanation of the recent past "by means of life histories or personal recollections where informants speak about their own experiences" (Henige, 1982, p. 2). It therefore refers to the method "by which oral information about the past is collected and recorded" and to "the body of knowledge that exists only in peoples' memories" (Allen \& Montell, 1981, p. 23). It differs from an oral tradition, which is the recollection of the past

1 This paper was presented at a meeting of the History of Education Society in 'Toronto, Canada on November 5, 1988. The suggestions of R.S. Patterson and N. Sutherland on an earlier draft of this paper are sincerely appreciated. 
commonly or universally known in a given culture (Henige, 1982, p. 2). As such oral history may be seen as having two purposes. On the one hand, it functions as a source of original or primary data not available in the documentary record. On the other hand, it may supplement or complement the written record by providing an insider's perspective and, in so doing, reaffirm existing data with an intimate "hands on" perception of events (Allen \& Montell, 1981, pp. 15-18). These objectives of course are not mutually exclusive, but in the process of "filling in the gaps" and leading to a fuller account of events, one or the other may become prominent (compare, for example, Gillett, 1981).

The pursuit of objectivity brings into focus the fundamental distinction between history as the existential events of the past, their actual occurrence irrespective of whether or not they were in any way recorded, and their subsequent interpretation (Tosh, 1984, pp. 11-12). Noting the importance of interpretation, E.H. Carr remarks that the facts of history

are like fish swimming about in a vast and sometimes inaccessible ocean; and what the historian catches will depend, partly on chance, but mainly on what part of the ocean he chooses to fish in and what tackle he chooses to use-these two factors being, of course, determined by the kind of fish he wants to catch (Carr, 1964, p. 23).

For historians of oral history, Carr's observations suggest that history as "what actually happened" is at best an ideal of historical knowledge precluded by idiosyncratic elements and especially social forces which enter into the interpretation of the past. If this is the case, then the oral historian's concern with objectivity must be seen in perspective not only of the life histories and personal recollections of the historical subjects, but in the light of various techniques employed by the historian to achieve historical knowledge.

Both the limits and possibilities of objectivity in oral history might be explored with reference to the emergence of educational leadership in Alberta from 1945 to 1970. The following specific questions come to mind: How were educational leaders identified and the data pertaining to their activities collected? In what way does the new knowledge of oral history regarding educational leadership contribute to a superior explanation of events? And, perhaps most importantly, is it possible to identify the criteria by which such objectivity is to be assessed, especially if those criteria are subject to the historian's conceptual framework and perception of events? If the key to an understanding of objectivity in an oral history of educational leadership centres on questions pertaining to the selection of data, then it is necessary not only to identify methodological concerns about the reconstruction of events but, as a point of reference, to provide a brief description of the existential conditions during the period under investigation. 


\section{(a) The Historical Setting}

Along a roughly drawn line centred on the year of passage of the Alberta School Act of 1970, a divide can be sketched on the historical topography of Alberta from which the waters of educational development can be seen to flow in very different directions. For 25 years following the conclusion of World War II, the rivers of educational change had flowed strongly and surely along sometimes turbulent courses that nevertheless were well defined and firmly channelled. These were years of dramatic expansion in the scale of publicly financed educational service, and also in the nature of these services which were broadened and enriched from elementary to postsecondary levels of education (see, for example, Berghofer \& Vladicka, 1980, pp. 16-17; Kach \& Mazurek, 1985, pp. 40-41; Sheehan, 1986, pp. 45-47).

Developments in education following 1945 were significantly influenced by economic, social, and demographic forces (compare with pre-war events in Patterson, 1970, pp. 363-70). Among the critical changes was an emphasis on universal and equal access to education. A demand for increased educational experiences influenced by a growing population and returning war veterans led to an expansion of vocational and technical education (Swift, 1958, p. 90). Response to this demand saw the implementation of a wide range of educational programmes, and by the end of the 1960) a shift in emphasis in government involvement from the direct administration of such programmes to coordination and decentralization. These events, along with the expansion and transfer of teacher education to the university, provided fruitful ground for the demonstration of educational leadership.

In this setting it was assumed that leadership involved the determination of solutions to educational problems that in their implementation included the mobilization of professional and public support (Selznick, 1957, p. 61). Based on this understanding, a first step in establishing the data of oral history required the determination of "significant sources" (see, for example, Dunaway \& Baum, 1984, p. 37; and Tuchman, 1984, pp. 74-78). To this end, educational leadership was examined at the provincial level with attention to four "significant" individuals who held publicly identified positions on the provincial stage. Through an extensive series of tape-recorded, transcribed interviews that included over 70 hours of audio tape, attention was given to the recollections of T.C. Byrne, Deputy Minister of Education in Alberta (1966-1971); H.T. Coutts, Dean of Education at the University of Alberta (1955-1971); S.C.T. Clarke, the Executive Secretary of the Alberta Teachers' Association (1959-1969); and G.L. Mowat, Chairman of the Provincial Board of Post-Secondary Education (1967-1968). Their contributions reflect a close involvement with attempts to resolve a number of educational problems, and efforts to mobilize professional and public support. In representing different constituencies, these educators on occasion expressed divergent views on educational matters, though all had similar backgrounds. All four grew up in rural or small-town Alberta. Three of them-Coutts, Byrne, and 
Mowat-received their early teacher education in Alberta normal schools, and all four completed their doctoral degrees at American institutions. Only Coutts studied at a Canadian university other than Alberta, completing his B.A. at the University of Toronto.

In the collection of evidence, it was assumed that Coutts, Byme, Mowat, and Clarke as representatives of province-wide constituencies were in a unique position to influence the resolution of educational problems that arose within the wider community (compare with Thompson, 1984, p. 48). Their positions of authority did not necessarily remove them from the day-to-day concerns of teachers, parents, and children in matters of education. Their views were elicited in response to two kinds of questions. The first set of questions was of a general, free-flowing nature exploring from a chronological perspective the individuals and the social factors that influenced their activities. The second set of questions given towards the end of the interviews was structured in terms of their understandings of education, leadership, and the relationship of education to society.

\section{(b) Oral History and Knowledge of Educational Leadership}

It may be argued that oral history contributes to two kinds of knowledge unavailable to the historian from the existing record. First, there is evidence pertaining to the lives of the educators, noting, for example, their likes and dislikes and their views of education. Second, there are data concerned with principles of educational leadership filtered through the perceptions of the educators themselves. These kinds of knowledge, though not mutually exclusive, will for purposes of illustration be considered separately.

In relation to the first kind of knowledge, attention might be given to the mutual understanding or the "we" feeling that pervaded Alberta education in the $1950 \mathrm{~s}$. Coutts, for example, remarked "that leadership in all the organizations whose primary reason for existence was public education was in the hands of people who had an understanding and trust in one another" (Hodysh \& McIntosh, 1982, p. 169). The point is reinforced by Clarke who noted that collegiality in the form of a "friendship group" was founded on "shared ideas, on good communication, and on respect for the roles the various members had to play" (Hodysh \& McIntosh, 1985, p. 62). As Mowat observed, there was a "very supportive feeling" and "good relationship" between officials in the Department of Education and members of other organizations. After all, Alberta in terms of population was small relative to its present size, and the "friendship and mutual respect among these people made it very easy for them to discuss common educational interests" (McIntosh \& Hodysh, 1988, p. 36). In the light of educational developments during this period, the historian might infer from the documentary record that a cooperative attitude did indeed exist. Its "objective" proof, however, requires more than an assumption.

Perhaps a more intriguing example of new evidence relates to the difference of opinion between Byrne and Mowat over the methods employed by the Board 
of Post-Secondary Education in achieving its goals. According to Byrne, the issue on which they disagreed was on the formation of a commission for the governance of colleges. "I insisted," argued Byme, "that...there should be only one post-secondary agency directing both colleges and universities....and this was best to be accomplished through the Department of Education" (Mctntosh \& Bryce, 1977, p. 60). It led Byrne to lecture Mowat "about parliamentary and non-parliamentary government, but.... l can assure you $I$ never won any argument with Gordon Mowat on this one" (McIntosh \& Bryce, 1977, p. 62). Mowat, on the other hand, claimed that his proposal of an administrative body outside of the direct control of the bureaucracy of the Department ensured a "face-to-face" presentation and defence of recommendations with the Minister. He concluded that the government's decision to opt for his rather than Byme's proposal was based on nothing more than "the relative merits of the opposing views" (Mclntosh \& Hodysh, 1988, p. 69).

In relation to a knowledge of ideas and principles leading to an "unbiassed" understanding of leadership itself, all of the individuals commented on those qualities that entered into the process of educational decision-making. Coutts identified not only "flexibility" but "the ability and drive to work hard and purposefully" as factors in leadership (Hodysh \& McIntosh, 1982, p. 163). Byme considered change and deviation from expected pattems of leadership as "refreshing" and beneficial to large established organizations, especially "if you follow a very orthodox person" (Mclntosh \& Bryce, 1977, p. 90). Reflecting on his own appointment as Executive Secretary of the teachers' association in the late 1950s, Clarke concludes that leaders invariably represent the aspirations of the organizations which they serve (Hodysh \& McIntosh, 1985, p. 51). Mowat corroborates this view when he observes that the leader is also a facilitator who not only has "goals of one's own," but has an ability to understand various positions, uncover common ground, and "to crystallize agreement on one point and move on to another" (McIntosh \& Hodysh, 1988, p. 73).

Oral history is also the occasion for obtaining a "hands on" view of events, thereby supplementing the documentary record (Allen \& Montell, 1981, pp. 15-18). Reference can be made to observations regarding the changing nature of authority and leadership. Noting the current procedure implemented at the University of Alberta in the late 1960s of restricting administrative appointments to five years with a possibility of renewal, Coutts remarks that in the founding period of the Faculty, when "we were fighting...for recognition of education as an accepted part of the university community; for recognition of the study of education as a discipline in its own right," it was important, when needed, not to have limited the length of such assignments (Hodysh \& McIntosh, 1982, p. 76). Coutts is quick to point out, however, that changing educational conditions have since contributed to the possible justification for the current practice. The recognition of changing leadership roles is equally noted by both Clarke (Hodysh \& Mclntosh, 1985, pp. 60-61) and more particularly Mowat (McIntosh \& Hodysh, 1988, p. 34). Mowat attributes this altered perception to "the changed 
nature of the educational community," and specifically in the activities of school superintendents "to the growing independence of local school systems" (McIntosh \& Hodysh, 1988, p. 37). The "higher level of education of teachers and administrators" has allowed these systems to be less reliant on outside authorities and, hence, the changing role of educational leadership.

A different illustration of "objective" supplementary knowledge relates to the broadening of the secondary school curriculum in the newly developed comprehensive high schools. "Although we were often accused of being antiacademic," Byrne remarks, "we began to look to the large regional high schools which could offer a wide range of programmes" (Mclntosh \& Bryce, 1977, p. 29). The need to exchange views regarding the nature of these schools identifying both their success and failure led to the founding of a provincial-wide conference, an idea attributed to Mowat (McIntosh \& Bryce, 1977, p. 30). The study groups which emerged from the initial conference provided the principals of the large schools "with an opportunity to meet together to discuss problems and identify issues" (Mclntosh \& Bryce, 1977, p. 31).

The documentary record indicates that educational change was occurring at a rapid rate during the mid-century period. It was especially evident in the federal government's creation of the Technical and Vocational Assistance Act in 1961 (Stamp, 1970, p. 462), an act which along with certain local developments had a significant effect on the Faculty of Education at the University of Alberta. The Act provided for an expansion of vocational education facilities for training and retraining skilled workers. At the university, a Department of Industrial and Vocational Education had the support not only of Dean Coutts but others in the wider educational community, including the President of the University (Hodysh \& McIntosh, 1982, p. 91). The Industrial Arts side of the programme came under the guiding influence of Dr. H. Ziel who emphasized Industrial Ants "as part of general education" (Hodysh \& Mclntosh, 1982, p. 92). Quoting H.C. Newlanda strong leader of the activity movement in Alberta during the $1930 \mathrm{~s}$-Coutts remarks on "the persuasiveness" of Ziel in establishing this direction. "We are on our way -we don't know exactly where we are going-but the great thing about this is we can never go back" (Hodysh \& Mclntosh, 1982, p. 93). However invaluable such insights may be as a way of providing original as well as complementary knowledge into the post-1945 period, there is a need to test the objectivity of that knowledge against the documentary evidence.

\section{Selection, Imagination and "What Actually Happened"}

In the light of an oral history approach to a study of the past, how appropriate is the claim that the historian's knowledge of educational leadership represents what actually happened? Such a claim invariably reminds us of Carr's observation that the historian's interpretation depends not only on the available evidence but the purpose which it serves (Carr, 1964, p. 23). It focusses on the principle 
that "all historical construction," as Dewey remarks, "is necessarily selective" $(1959$, p. 167). The first selection, of course, is made by the individuals whose history is being investigated. In the case study of oral history this relates to the recollections of Coutts, Byme, Clarke, and Mowat, each of whom has selected particular events and ideas from a wide range of existential phenomena in which they were involved. Whether their observations pertained to the cooperative nature of educational activities among organizations noted by Coutts and Clarke, or Byrne's personal observations regarding his differences with Mowat, they represented that which they considered in retrospect to be important from numerous events that occurred. Moreover, the understandings of Mowat and Byme, for example, indicated alternative perspectives on a given event.

Of fundamental importance is the recognition that the recollection of such events occurred some thirty years after the events themselves. This suggests two possible shortcomings. First, memory is not only selective but may also be faulty. Was the cooperation among the educational leaders, for example, as evident then as it appears to be now? And further, were the observations of Coutts on the nature of term administrative appointments coloured by the perception of recent educational events? Second, whether or not these questions are answered in the affirmative, they suggest that the reconstruction of historical events from the standpoint of oral history allows the individual to influence the way in which the course of those events are themselves interpreted (Sutherland, 1988, p. 18). Put differently, the historical record incorporates a knowledge of educational leadership not extant at the time in which it occurred, for the idea of the term appointment, as an example, was not the standard administrative condition during the immediate post-war period; and, hence, any allusion to its efficacy or lack thereof by either the educational leader or the oral historian is in a sense an unavoidable addition that may affect "what actually happened."

A further selection is made by the historian. The meaning of educational leadership influenced not only the historian's selection of organizations, but also the identification of critical individuals as leaders of the group responsible for educational planning. Immediately, the historian has narrowed down the broad range of educational history to particular events and the activities of those considered to be "significant" individuals. In turn, the dialogue between the historians and the educational leaders was shaped in part by the questions which were explored and the responses which were further selected. The historian becomes the arbiter of the relative weight and relevancy of the recorded data, and in their connection with one another the way they are to be ordered (Dewey, 1959, p. 169). Having selected that which the participants in the existential events have already selected, the historian contributes to the meaning of historical objectivity and that which occurred.

Now it may be argued that the selection of historical evidence concerning educational leadership is nothing more than the required exercise of historical imagination - the way in which the truth of events through description and explanation is brought into view. This match of interpretation with past existen- 
tial reality might be achieved in many ways. Although models of a sociological or psychohistorical nature are often employed to present the results of oral history, attention might be directed to the views of R.G. Collingwood who links the explanation of events to the thought behind historical actions (1956, p. 213). On the basis of this principle, it is argued that the attempt to probe the reasoning concerning the course of events allows the historian the best opportunity to understand the nature of educational developments as they were manifest from the perspective of any one leader. Only in this way does the oral historian achieve an objective and "superior" explanation.

In determining "what actually happened," the historian may go beyond selection to discover not only the event, "but the thought expressed in it" (Collingwood, 1956, p. 214). Arriving at Clarke's understanding of leadership, for example, requires more than a recognition of his role as Executive Secretary of the Teachers' Association. It entails a re-enactment or re-thinking of his actions as they pertained to cooperation, trust, and liaison in the educational community. In the process, therefore, of exercising such historical imagination, the oral historian attempts to establish "what actually happened." However, is it possible in an objective way to re-think Clarke's thoughts? (See, for example, Patterson, 1986, pp. 99-106.) If so, can it be assumed that his recollections regarding conditions of educational leadership are identical to the thoughts as they occurred in the 1950s? (Compare with Edel, 1984, p. 40). Collingwood's technique is of course but one way of establishing an "objective" presention of events, standing as it does alongside Walsh's method of colligation and other forms of historical description and explanation (Walsh, 1974). Notwithstanding the acceptance of Collingwood's technique by many historians, is it possible that given its apparent shortcomings, the method as a means of arriving at "objective" knowledge is at best only a way of proposing hypotheses?

\section{Oral History and Criteria of Objectivity}

However the problem of objectivity in oral history is viewed, it would seem that the historian plays a critical role in the interpretation of events. Indeed, the entire process of selection so central to the presentation of post-war educational leadership in Alberta reflects this concern. The historian is not only dependent on the evidence which the leaders bring to the description and explanation of events but, perhaps unknowingly, on the cultural baggage that shapes the intellectual framework or paradigm that guides the selection of evidence (Kuhn, 1970, p. 175). More specifically, the social group to which the historian gives allegiance and the notion of what elements enter into educational change provide an orientation to education and historical interpretation that sets the conditions for the selection and organization of oral history data (Mommsen, 1978, p. 23).

The theory-laden nature of the oral historian's intellectual framework influences not only the "objective" presentation of "what actually happened," but 
also the further step of whether or not it is possible to establish criteria by which the meaning of objectivity itself can be assessed. For example, among the criteria frequently associated with a "better" interpretation of events is that of accuracy (Kuhn, 1977, p. 338). This criterion is evident when data and concepts are in agreement with understandings of educational leadership established not only by means of the written record, but in the interviews with the leaders and their recollections of the past (Hodysh, 1987, p. 88).

If this is the case, it would seem that accuracy as a criterion is subject to the historian's conceptual framework and perception of events. To cite but one illustration, in identifying the cooperative element among the leaders, the researchers approached the inquiry with a particular understanding of what might constitute educational leadership. Moreover, on the basis of the established documentary and oral data, they introduced the notion of the "family compact" as representing among the leadership a "we" feeling in their view of the educational issues of the period. The use of the term "family compact" sets a direction, much like a hypothesis, to the kind of data brought forward by the leaders (Hodysh \& McIntosh, 1982, p. 120; and Hodysh \& McIntosh, 1985, p. 62). It required the subjects to respond with specific reference, for example, to the extent of collegial relations between the Faculty of Education and the Teachers' Association. The result is objective only from the standpoint of what assumptions enter into the accuracy of the particular event. In this instance, the description and explanation of the historical conditions is based in part on terminology and understandings of what constitutes leadership in education. Thus the criterion of accuracy cannot be separated from the historian's assumptions which knowingly or otherwise enter into the interpretation of the past.

\section{Conclusion}

The study of objectivity in oral history suggests that two constituents of methodology be given special attention. First, the historian should be aware of the values and assumptions that inform his or her personal perspective on history and, more particularly, the models employed in historical research. The awareness of assumptions does not refer to a casual familiarity that may easily be overlooked, but rather to an understanding that alerts the historian to the impact of the assumptions on the selection of evidence-and why, perhaps notwithstanding the best efforts of the investigator, some data are chosen while other data of equal importance are ignored. Where possible, the recollections of oral history should be employed in concert with documentary evidence, not only to verify the understandings of the subjects, but to gather as much evidence as possible in order to increase the quantity as well as perhaps improve the quality of data to be used in the description and explanation of events. Second, the historian's use of general and specific hypotheses should only be taken as guides in the framing of oral history data. For the historian, this implies the exercise of a methodological 
reserve or humility. Without negating the importance of the historian's commitment to a particular hypothesis and perspective of events, such an attitude - a kind of detachment to one's own biases and predictions in keeping with the best ideals of research-allows for the inclusion not only of data that supplement or challenge what the historian has already selected, but perhaps within the same work, interpretations that may complement the one with which the historian is primarily concerned. These methodological judgements, though not putting the problem of objectivity to rest, may contribute to the continuing effort to provide a better and, perhaps, superior explanation of events.

It is evident that the attainment of objective historical knowledge is a controversial task, for the determination of "what actually happened" is dependent, as Carr implies, on a presentism that both the subject and the historian are unable to escape. One could agree with Voltaire that all too often history represents the tricks of the living played upon the dead (Krug, 1967, p. 4). This claim makes for imaginative repartee, yet it does not deny the need to reflect on the purpose of oral history, its promise, and its inherent limits. It is, after all, the task of each generation to reconstruct both the past and the tools by which that reconstruction is to be achieved.

\section{REFERENCES}

Allen, B., \& W. Montell (1981), From memory to history. Nashville: American Association for State and Local History.

Berghofer, D., \& A. Vladicka (1980). Access to opportunity 1905-80. Extmonton: Alberta Education Communications Corporation.

Carr, E.H. (1964). What is history? London: Pelican.

Collingwood, R.G. (1956), The idea of history. London: Oxford University Press.

Dewey, J. (1959). "Historical judgments," in The philosophy of history in our time, ed. H. Meyerhoff (pp. 163-72). Carden City, NY: Doubleday \& Company.

Dunaway, D., \& W. Baum, eds. (1984). Editor's introduction, in Oral history (p. 37).

Nashville: American Association for State and Local History.

Edel, L. (1984). Writing lives. New York: W.W. Norton \& Company.

Gillett, M. (1981). We walked very warily: A history of women at McGill. Montreal: Eden Press Women's Publications.

Gorman, J.L. (1981). "Precision in history," in Substance and form in history, ed. L. Pompa and W.H. Dray (pp. 120-32). Edinburgh: The University of Edinburgh Press.

Henige, D. (1982). Oral historiography. London: Longman.

Hodysh, H.W. (1987). "Objectivity and history in the study of higher education: A note on the methodology of research," Canadian Journal of Higher Education 17: 83-93.

Hodysh, H.W., \& R.G. McIntosh (1982). Conversations with a dean: The life and times of H.T. Coutts. Special issue of Challenge in Educational Administration 21: 1-192. Edmonton: Alberta Teachers' Association.

Hodysh, H.W., \& McIntosh, R.G. (1985). Leadership in the teaching profession: Conversations with Stanley C.T. Clarke. Special issue of Challenge in Educational Ad. ministration 24: 1-68. Edmonton: Alberta Teachers' Association. 
Kach, N., \& K. Mazurek (1985). "Social change and curriculum reform in Alberta, 1957-1971: A case study," Education and Society 3: 35-44.

Krug, M. (1967). History and the social sciences. Waltham, MA: Blaisdell Publishing Company.

Kuhn, T.S. (1977). "Objectivity, value judgment and theory choice," in The essential tension (pp. 320-39). Chicago: The University of Chicago Press.

Kuhn, T.S. (1970). The structure of scientific revolutions. 2nd ed. Chicago: The University of Chicago Press.

Mclntosh, R.G., \& R.C. Bryce (1977). Conversations with Tim Byrne: Reflections on education in Alberta. Special issue of Challenge in Educational Administration 15: 1-107. Edmonton: Alberta Teachers' Association.

McIntosh, R.G., \& H.W. Hodysh (1988). The quiet leader: Conversations with Gordon L. Mowat. Special issue of Challenge in Educational Administration 26: 1-75. Edmonton: Alberta Teachers' Association.

Mommsen, W.J. (1978). "Social conditioning and social relevance," History and Theory 17, 4: 19-35.

Patterson, R.S. (1970). "Society and education during the war years and their interlude," in Canadian education: A history, ed. J.D. Wilson, R.M. Stamp, \& L.P. Audet (pp. 360-84). Scarborough, Ontario: Prentice Hall.

Patterson, R.S. (1986). "Voices from the past: The personal and professional struggle of rural school teachers," in Schools in the west: Essays in Canadian educational history, ed. N.M. Sheehan, J.D. Wilson, \& D.C. Jones (pp. 99-111). Calgary: Detselig.

Ranke, L. von. (1956). "Preface: Histories of the Latin and Germanic nations from 1494-1514," in The varieties of history, ed. F. Stern. Cleveland: The World Publishing Company.

Selznick, P. (1957), Leadership in administration. New York: Harper \& Row.

Sheehan, N.M. (1986). "Education, society and the curriculum in Alberta: An overview," in Schools in the west: Essays in Canadian educational history, ed. N.M. Sheehan, J.D. Wilson, \& D.C. Jones (pp. 39-56). Calgary: Detselig.

Stamp, R.M. (1970). "Government and education in post-war Canada," in Canadian education: A history, ed. J.D. Wilson, R.M. Stamp \& L.P. Audet (pp. 444-70). Scarborough: Prentice-Hall.

Sutherland, N. (1988). "'Listening to the winds of childhood': The role of memory in the history of childhood," Canadian History of Education Association Bulletin V: 5-29.

Swift, W.H. (1958). Trends in Canadian education. Toronto: Gage.

Thompson, P. (1984). "History and the community," in Oral history, ed. D. Dunaway \& W. Baum (pp. 37-50). Nashville: American Association for State and Local History.

Thompson, P. (1978). The voice of the past, oral history. Oxford: Oxford University Press.

Tosh, J. (1984). The pursuit of history. London: Longman Group Limited.

Tuchman, B. (1984). "Distinguishing the significant from the insignificant," in Oral history, ed. D. Dunaway \& W. Baum (pp. 74-78). Nashville: American Association for State and Local History.

Walsh, W.H. (1974). "Colligatory concepts in history," in Theories of history, ed. P. Gardiner. Glencoe: The Free Press. 